\title{
THE ROLE OF UNIVERSITIES IN ACHIEVING SUSTAINABLE DEVELOPMENT OF SOCIETY THROUGH UNIVERSITY YOUTH
}

\author{
Raghad Zaki GHAYAD, Fawzi snake FORGOTTEN *
}

College of Basic Education, Al-Mustansiriya University, Iraq.

\begin{abstract}
University education is the basis within which many personal traits of learners grow, and the value of any educational system is determined by its ability to achieve its goals, as education is considered one of the most important components in peoples' lives, as it is through it that human thought, cultural and political awareness, and social role are formed. The criteria for success and failure in any educational system lies in the ability of that system to achieve its goals, or its failure to do so. In view of the exposure of societies - in recent decades to many changes that included various aspects of life, which had a direct impact on what society and its institutions expect from education, it became necessary for this to be accompanied by a change in the objectives, contents and methods of education. And since the educational system is part of the societal system that educates the individual and prepares him for his contemporary and future life, the roles of community institutions overlap with each other, and their roles are complementary in order to provide the individual with knowledge, trends and values to shape the person's personality and behavior as it is the basis for achieving sustainable development for his society. Modern must be accompanied by human building to meet the challenges of the times.

Keywords

Universities, Achieving, Sustainable Development, Society, Youth.
\end{abstract}

\section{Introduction}

Universities are one of the main pillars on which the advancement and growth of society is based, because it is the academic scientific institution that works to prepare the human resources needed by community development plans, which are five-year or ten-year, that strategic planning scientists put in any society, envisaging the needs of the future in order for growth in it to be sustainable. Universities provide all institutions with the specializations and human cadres necessary for the requirements of comprehensive development in society.

Universities play a fundamental role in the development process because they are responsible for meeting the needs of society in terms of manpower equipped with intellectual and professional skills, and they are also responsible for educating people psychologically and socially, which makes it easier for him to accept social change.

Universities that represent higher education are at the top of the educational and educational system hierarchy, to prepare human resources that respond to the requirements of comprehensive and sustainable social development. Therefore, a serious and important task must be assigned to them, which is to formulate young people and strengthen their belonging to their community and their concerted endeavor to contribute to its intellectual, cultural, emotional and skill development. The top leaders of society in various scientific, economic,

*Corresponding author: Education@uomustansiriyah.edu.iq 
political, administrative and cultural fields are university graduates, so as much as these universities can teach and educate people to use the scientific method in solving problems and train them to make decisions, adapt to new developments, and gain creativity in the field of their specializations As far as the progress and development of society will be, on the contrary, the society will remain in its place or retreat backwards. The independent role that universities play in promoting the manifestations of rationalization, rationality and objectivity among their students, would give society a future reassurance that allows the formation of various innovations ready to face the challenges that contribute to preventing the disruption of sustainable development in it.

University education increases students' scientific competence, increases their ability to face and solve life's problems, and helps develop their skills.

The issue of securing sustainable development in any society is based on the ability of its people to confront any new requirement in their lives with skill to overcome problems and solve them by submitting them to the language of reason and logic.

The quality of achieving sustainable development is linked to the principle of rationalizing consumption, so the more development is achieved with a lower level of spending, the more and wider the means to achieve newer horizons for that development. Family and rapid adaptation to changes and developments.

The quality of higher education in its university institutions does not lie in teaching students facts that end to being forgotten upon obtaining an achievement success, but in the consolidation of these facts and their conversion into creative applications in society. Most universities in developing countries need reform and they are in front of a long way to go.

This is the aim of the curriculum in its modern sense, as it is a set of experiences that students gain from the overall elements of the educational process, whether planned or unplanned, and this requires creative teaching by university education academics who hold specializations with which no one competes with them, but the reality of the situation carries dissatisfaction with what learners graduate in general. And the Arabs, especially from their universities, which has its traditional origin in the university educational system and its lack of openness to the developments of modern life, and this has been confirmed when, "Many countries prevail in dissatisfaction with students' achievements arising from the poor educational system, and they also realize the inconsistency between educational outcomes and needs. the society.

Here, the importance of the current research is evident in its contribution to setting descriptive criteria for what the university institution must undertake in order to achieve sustainable development in a society that is considered a youth group. 


\section{The second semester (theoretical - procedural axis)}

University education is linked to the concept of universality, as it prepares the university student to be more coexistent with what is happening in the world in terms of events and in line with what he is witnessing in terms of developments in all levels and fields. If we want to face the challenges of the times, protect ourselves and our homelands, and secure a decent life for our citizens, we must create research institutions capable of The performance of its tasks with this open characterization that prepares university youth for a balanced and productive life in the field of their specialization contributes to the mobility of society and addresses its crises and does not depend on the short view of university education which led our youth to loss after graduation and the transformation into unemployment whose life leads away from the field of university degree that does not represent more than a plate attached to it. The halls of their homes prove their belonging to the educated class.

The concept of sustainable development through the university moves away from mere subjects studied by the student to graduate and goes beyond that by preparing him to obtain opportunities and face the demands of life in all its aspects in order to be able to achieve the demands that lead to the development of society in sustainable development.

The universities in the Arab world in general are based on their philosophies and ideologies on a system of perceptions and beliefs that prevent their representation of social change, as they still prepare students without attention to the real development needs of knowledge and skills, which led to the Westernization of these students and the sterility of the knowledge they acquire while they are still falling short in Its role in the formation of political awareness, the social personality belonging, and the actor in public life.

The development of sustainable societies does not necessarily mean that all of its children should be doctors and engineers, as societal growth needs middle cadres, manpower, craftsmen and industries more broadly than the need for a number of doctors who are not proficient in practicing their profession and its conditions, and how many other engineers working in car showrooms or Ready-to-wear boutiques.

The idea of sustainable development goes back to a photo report from the Club of Rome in the year 1950 on the limits of environmental growth and the discussions of activists in that field. At that time, the International Federation issued in the same year a report entitled The Global Strategy for Nature Conservation, on the basis of which the distinction between development and the environment was removed to produce a term called sustainable development .

The advocates for the concept of sustainable development continued until the Second Earth Summit in 2009 in Johannesburg, which was held under the slogan (World Summit on 
Sustainable Development).

Sustainable development can be viewed as an ethical commitment from the current generation to the next generation that guarantees environmental, scientific and economic stability for each of them without overlooking the requirements of a renewed life.

The two researchers believe that sustainable development is related to the term foreseeing the future, meaning predicting it, so it is not possible to know what we should provide for our children unless we are stable for their coming days, and although the path of life and days are subject to the will of a dear and mighty one, but it is the most glorious and glorious that he granted his servant a trust that required him until he made him his successor on his land To live, revive and contribute to its sustainability.

\section{Results:}

The results of the research resulted in data and information that define the principles and trends provided by universities as an educational institution, and also resulted in the identification of a number of functions that the university must perform in order to build people and prepare them to face the developments and changes sweeping the world today, and the results will be presented arranged according to the axes of the questionnaire adopted in the research The mechanisms described above have already been explained:

First: Roles based on future foresight, including:

1 - That the university prepares the young generations to establish the future that society wants.

2- Establishing a broad structure for a set of potential future prospects emerging in every specialized field.

3- Preparing university youth to face the monotony and slow rhythm of community life so that their society does not lag behind the acceleration of other societies.

4- Developing their communication capabilities in their fields of specialization in line with the growth of the fields of communication sciences.

5- That universities work to create human and emotional youth who are prepared to fulfill integrative roles in their professional community.

6- That universities provide societies with young people who do not suffer from any deficiencies in the economic, social and ethical thinking required by all fields of work.

7- Every university should develop a special plan for sustainable development in light of which it draws its admission plans and curricula.

8- That universities, which are increasingly demanding of society, grant their majors a higher value in society through media and national support to encourage demand for them.

Second: Roles based on academic curricula, including: 
1- Achieving fundamental changes in the application of university curricula in line with technological expansion.

2- That universities conduct administrative and organizational treatments that facilitate the disadvantaged sectors of youth to complete their university education.

3- That sustainable development plans be commensurate with the nature and aspirations of the Arab community.

4- To take into account the principle of universality in designing university curricula, $d$. The curricula must be comprehensive at the level that meets the current and future challenges in every specialized field.

Third: Organizational roles consistent with the requirements of sustainable development and include:

1- To provide a pre-description of its outputs so that the young university graduates are aware of what they should be upon their graduation.

2- Setting pre-acceptance criteria consistent with describing the outputs.

3- That the output specifications and acceptance criteria be formulated in line with the requirements of achieving sustainable development in society.

4- To provide its students with specialized teaching staff at a high level of professional, ethical and academic numbers.

5- Structuring university and higher education to meet the challenges facing the Arab world at all levels and the widening gap between developed and developing countries.

6- Reviewing the university's mission and examining the extent of its success or failure to achieve its goals.

7 - That the university provides scientific guidance, within or outside the curriculum, to guarantee the university education year and make it serve the people of today and the people of tomorrow, which is the first goal of sustainable development.

8- Developing prior strategies to confront organizational, educational, or societal crises without causing any hindrance to the course of the educational process in universities.

9- Providing laboratories and workshops necessary for specialized academic experience in every field of university education.

Fourth: Ethical roles that include:

1- Training young university students to deal positively with the issues of their professional life.

2- Training young university students to contribute to reviving their environments through their fields of specialization. 
3- Enhancing the value aspects that will revive and preserve the environment for future generations.

4- Training of young university students on positive competition and sportsmanship.

5- Attention to quality in performance more than speed and quantity.

6- Providing a culture of management and economics in every field of specialization because they are two basic aspects of sustainable development.

7- Training young university students to maintain and preserve material resources.

8- Providing university students with facilitating maintenance of funding sources and dealing with them wisely.

9- That universities provide marketing programs for their outputs so that they can have job opportunities upon their graduation, and this is the role of university media.

10- Preparing university students on the principles of logical thinking and scientific research in the field of their specialization to enable them to face the crises that may encounter them in their professional future.

11- Establishing the cultural identity of each society within its university specializations to ensure the permanence of this identity in an atmosphere of sustainable development.

12- Developing awareness of cooperative and voluntary work programs to serve the interests and needs of the social environment.

13 - Deepening the idea of integration with the other and not partisan with specialization.

14- Training young university students to respect the value of time and not to waste it.

Since the research only relied on frequencies and percentages, the researchers arranged the paragraphs in each axis in descending order according to what the research sample used in terms of the validity of the paragraphs to express the roles of universities in achieving sustainable development in society through university youth.

\section{Conclusions:}

The two researchers conclude from the results of the questionnaire that there is a (developmental) awareness among university students of the research sample, and this is in line with the role that this category is expected to play in achieving sustainable development. The community has experiences that qualify it to advance a renaissance program that ensures that wealth reaches future generations, and with regard to the role of universities in preparing students to play an effective role in achieving the goals of sustainable development, the results of the questionnaire showed an emphasis on the role of universities in creating the atmosphere and conditions that enable students to be active participants in this process 


\section{Recommendations:}

\section{In light of the research results, the researchers recommend the following:}

1- Proposing entrances for university education policy and its functions that combine innovation with realism. Establish strong and open communication channels between universities and community work sites - especially production centers.

2- Increase spending on universities, especially the allocations set for scientific research and directing it to solve community problems.

3- Focusing on the quality of education, and emphasizing the university's role in producing, developing and renewing knowledge.

4- Building generational thinking on concepts based on change, adaptation, and mobility, to gain the mind flexibility in thinking and openness to human knowledge.

5- Not only presenting the theories and ideas of sustainable development on papers and inside the halls of seminars and conferences, but rather it requires every individual in society, regardless of his position, to participate with decision-makers and help them implement development plans and programs.

6- Coordination between Arab universities, given that the Arab world is an integrated Islamic, Arab, economic and social unit.

\section{References}

1- Musnad, Sheikha. 12. The role of Qatar University in developing trends of modernity upon its students in light of some variables, Research Center Journal, Seventh Year, Thirteenth Issue, Qatar.

2- Parsons, T. (1977). Social systems and the evolution of action theory, New York: the Free Press

3- Bowen, H. (1997). Is higher education worth the cart? Investment in learning. Washington:

4- Jayox, Ev, K. (1996). A Framework for capacity building in policy analysis and economic management in Sub-Saharan Africa, Washington, Dc World Bank

5- Doglass, G. (1977). Economic versus investment in higher education, New York.

6- Kellaghan, T. (1999). Educational tests \& measurements. Assessment in Education: Principles, Policy, \& Practice

7- Ev, K. (1996). A Framework for capacity building in policy analysis and economic management in Sub-Saharan Africa, Washington, Dc: World Ban

8- Abu Al-Nasr, Medhat Muhammad. Human Resources Management and Development (Contemporary Trends), Arab Nile Group, 2009, Arab Republic of Egypt.

9- Morsi, Muhammad Ahmad, 1971, The Role of Jordanian Universities in Developing Trends 
of Modernity Upon Their Students, Journal of Social Affairs, Amman, Hashemite Kingdom of Jordan

10- Sahar Muhammad Othman DARGHAM, THE ROLE OF CONTEMPORARY ART IN MONITORING THE PHENOMENON OF ILLEGAL IMMIGRATION, International Journal of Humanities and Language Research, Vol. 3, No. 1, 2020, pp. 22-29.

Received: September 4, 2020

Accepted: November 28, 2020 